JPPUMA: Jurnal Ilmu Pemerintahan dan Sosial PolitikUMA (Journal of Governance and Political Social UMA), 9 (2) (2021): 139-149, DOI: 10.31289/ippuma.v9i2.5029

JPPUMA: Jurnal Ilmu Pemerintahan dan Sosial Politik UMA (Journal of Governance and Political Social UMA)

\title{
Analysis of Increasing Women's Participation in 2018 Governor Election in Maleer Village, Bandung, West Java
}

\author{
Ana Sabhana Azmy* \& M. Ricky Ridestian \\ Political Science Study Program, Faculty of Social and Political Sciences, \\ Syarif Hidayatullah State Islamic University Jakarta, Indonesia
}

Received: 20 March 2021; Reviewed: 27 March 2021; Accepted: 02 July 2021

\begin{abstract}
This article aims at analyzing the participation and behavior of women voters in the 2018 West Java Governor Election in Maleer Village, Bandung City. The study was conducted qualitatively, supported by primary data in observations and interviews with several sources. Secondary data was obtained from searching for several references, either through books, journals, or other supporting data. The results of this study showed that the participation of women in the 2018 West Java govern or election was $79.16 \%$, higher than the participation of men at $74.26 \%$. Several factors encouraged women to exercise their right to vote in the 2018 West Java governor election in Maleer Village, Bandung City, referring to Myron Weiner's theory, namely modernization, mod ern mass communication, and conflicts between groups of political leaders. Modernization was followed by the more active involvement of women in public spaces, modern mass communication, that female voter use d mass media technology as a preference in voting, and an increase in identity politics has occurred since the 2017 DKI Jakarta Regional Head Election. It has had an impact on the 2018 Governor Election. There was polarization in society. In terms of voting behavior, women in Maleer Village chose figures based on psychological choices and rational choices. The psychological selection of female voters on candidate figures was based on social media for governor candidates as a means of interaction with the community. Meanwhile, the rational choice of female voters was based on looking at the program or work of a candidate for governor who was an incumbent figure (previously serving). Women assess what impact they have had while the candidate for governor (who was the incumbent) was in office and find out whether previous programs have been beneficial or not for them as a woman.
\end{abstract}

Keywords: Political Participation; women; Voter Behavior; 2018 West Java governor election.

How to Cite: Azmy, A.S., \& Ridestian, M.R. (2021). Increasing Women's Participation in the 2018 Governor Election in Maleer Village, Bandung, West Java. JPPUMA: Jurnal Ilmu Pemerintahan dan Sosial Politik UMA (Journal of Governance and Political Social UMA), 9 (2): 139-149

*Corresponding author:

E-mail: azmy@gmail.com
ISSN 2549-1660 (Print)

ISSN 2550-1305 (Online) 


\section{INTRODUCTION}

The General Election or Election is a democratic party that is awaited by the community and is an arena for the legitimacy of the people's sovereignty over a government, both executive and legislative. Political participation is a key factor in a successful election. If the level of political participation is low, then the level of democracy can be called undoubted (Sahid, 2011). Based on Herbert McClosky in Miriam Budiardjo, political participation is activities without coercion from citizens by taking part in electing heads of StateState or regional authorities and indirectly or directly influencing the processes of forming public policies. (Budiarjo, 2013).

Through Law Number 10 the Year 2016 (Judith.Jakarta.go.id, 2016) regarding the second AmendmentAmendment to Law Number 1 of 2015 concerning Stipulation of Government Regulations instead of Law Number 1 of 2014 concerning the Election of Governors, Regents, and Mayors into Law, the 2018 simultaneous regional elections can be carried out based on that law. The 2018 simultaneous regional elections, which took place on June 27, 2018, were one of the democratic parties awaited by the people in various regions, especially the province of West Java which held the election of the Governor and Deputy Governor. West Java is one of 17 provinces that held simultaneous regional elections in 2018.

The 2018 simultaneous Regional Head Elections in West Java province were followed by four candidates, including Mochamad Ridwan Kamil and UU Ruzhanul Ulum, Major General TNI (Ret.) Hasanuddin and Inspector General of Police (Ret.) Anton Charliyan, Major General TNI (Ret.) ) Sudrajat and Ahmad Syaikhu, and Deddy Mizwar and Dedi Mulyadi. With the following four pairs of candidates, the level of participation increased. Noted that in the 2008 governor election, the public participation rate was at $67.31 \%$, the 2013 governor election, the public participation rate was $63.85 \%$ (Solehudin, 2004), and in the 2018 governor election based on KPU data, the public participation rate increased to $70.30 \%$ (Results ofDetermination of West Java at, 2018) which was that there was a significant increase after previously there was always a decline in the two governor elections. In this case, women used their right to vote more than men. There was no female candidate from the four candidates who competed in the 2018 West Java governor election.

Male Village, based on the votes obtained in the 2018 West Java Governor Election, placed the pair number 1 (Ridwan Kamil-UU Ruzhanul Ulum in the first position with a total of $54.73 \%$ of the vote, the second position was followed by Sudrajat-Ahmad Syaikhu (sequence number 3) with votes 23,91\%. Deddy Mizwar-Dedi Mulyadi occupied the third position with a vote of $12.25 \%$, and Hasanuddin-Anton Charliyan occupied the fourth position with a voice of $9.11 \%$ (KPU, 2018).

The victory of the Ridwan Kamil-UU Ruzhanul Ulum pair of $54.73 \%$ means that more than half the number of valid ballots chose pair number 1 . It was followed by the high participation of women in Maleer Village of $79.16 \%$. Therefore, women's reasons for selecting candidates need to be seen and investigated further as a focus in this study.

In the history of elections and women globally, women only had voting rights in the 1920s through the 19th AmendmentAmendment in the United States. However, the desire to participate involves all sectors of society, both men and women, has emerged slowly (Budiardjo, 2013). Women are half of the population of a country. If their participation is limited and there are inequalities in political decision-making and processes, they can state that a government is not fully democratic (Bibler et al., 2014). Talking about politics and women, it is inseparable from the social construction of women in public relations. The image formed has created a stereotype about women that women have not been able to enter the world of politics in the public world, including politics. The stereotype formed is also what makes women in domestic affairs while men in public affairs. This stereotype also causes social inequalities such as access to education, where fewer women have attained higher education than men. It also causes women's political awareness to below as a result of stereotypes that took root in society(Astuti, nd)

The patriarchal culture inherent in society and a male-dominated political system has a great discriminatory impact on women. Women are not supported and even hindered 
in their efforts to participate in political activities actively. The concept of public space and private space has discriminated against women in the electoral process, political parties, business work, and so on(Soetjipto, 2005).

This paper reviews the factors that encourage women to be more active in exercising their right to vote in the 2018 West Java governor election in Maleer Village, Bandung City. In addition, the researcher also reviewed how the behavior of women voters in the 2018 West Java governor election in Maleer Village, Bandung City, which was observed from the discussion of political behavior.

\section{RESEARCH METHOD}

This research was qualitative research with a case study. Lawrence Neumann (2013) explained that qualitative research used the rules of interpretive or critical social science. This study analyzed how women's participation in the 2018 West Java governor election as specified by looking at the case in Maleer Village.

The data collection technique in this study was through interviews with five (5) resource persons from the community, where the researchers chose resource people who could provide data. The researchers chose representatives from each R.W., namely one person from RW 03, 1 person from RW 01, 1 person from R.W. 02, 1 person from R.W. 05, and 1 person from R.W. 10. This was done so that researchers could get comprehensive information from female voters in Maleer Village, Bandung, West Java. In addition, the researcher interviewed one resource person from the government element, namely the Bandung City Election Commission, and one observer in the electoral matter from Prelude.

In addition to conducting interviews, the researchers also collect secondary documentation such as books, journals, theses, the internet, and others according to the research needs. Researchers found data about the role of women in politics, especially in elections, from books, journals, and other documentation. Thus, the researchers used these data in writing, especially the analysis of the discussion combined with the results of existing interviews. While the data analysis carried out was by looking at women's political participation during the 2018 governor election in Maleer Village, Bandung City, from the perspective of voter behavior that researchers did by asking the West Java KPUD.

\section{RESULTS AND DISCUSSION \\ Women's Participation in the 2018 West Java Governor Election}

Participation was a variable that could not separate from democracy. Voting could not be underestimated because the activities determine who the winner will be, the direction of policy, how the region or country will be in the future. The 2018 West Java governor election, in general, underwent an increase in people's political participation as voters when compared to the 2013 West Java governor election.

Table 1. Women's Participation Rate in Maleer Village, Bandung City in 2013(K.K. Bandung, 2013)

\begin{tabular}{llll}
\hline $\mathbf{2 0 1 3}$ West Java Governor Election & Man & girl & Total \\
\hline Number of Voters & 6.094 & 6.086 & $\mathbf{1 2 , 1 8 0}$ \\
\hline Number of Voting Rights Users & 4.032 & 4,503 & 8,535 \\
\hline \multicolumn{1}{c}{ Participation } & $66.16 \%$ & $73.98 \%$ & $70.07 \%$ \\
\hline
\end{tabular}

Source: Bandung City Election Commission

Participation in the 2013 West Java governor election in Maleer Village, which amounted to $70.07 \%$, was dominated by women with a participation rate of $73.98 \%$. These data were the same as the participation data in the 2018 West Java governor election, which women dominated, but the participation rate increased. Look at the following table details: 
Ana Sabhana Azmy \& M. Ricky Ridestian. Analysis of Increasing Women's Participation in

\begin{tabular}{llll}
\hline West Java Governor Election 2018 & Man & Woman & Total \\
\hline Number of Voters & 848,559 & 856,750 & $1,705,309$ \\
\hline Number of Voting Rights Users & 630.149 & 678.186 & $1,308,335$ \\
\hline Participation & $74.26 \%$ & $79.16 \%$ & $76.72 \%$ \\
\hline & Source: KPU RI & &
\end{tabular}

The number of female voters in the 2018 West Java governor election has increased from the 2013 West Java governor election. It is also accompanied by an increase in the participation rate of women from $73.98 \%$ to $79.16 \%$ in the 2018 West Java governor election, where almost half of the voting population is women and women in using their right to vote better than men should be a portrait that women's participation is significant. When the StateState excludes women, then it cannot state the country to be democratic. Achieving democracy requires genuine cooperation between women and men in carrying out community affairs where they work equally and complement each other. Their differences can enrich each other. (Bibler et al., 2014) In line with Helen Clark's statement (Bibler et al., 2014), "it is clear that democratic governance cannot be said to be fully achieved without the full participation and involvement of women".

Based on the participation rate in Maleer Village, the researcher found the factors that influenced the participation of women citizens in using their voting rights in the 2018 West Java Governor Election, as referred to the idea of Myron Weiner in Mas'oed \& McAndrews (1991), namely;

\section{1) Modernization}

Modernization with the characteristics of progress in all fields, improving education and the community's economy, and increasingly sophisticated mass communication media technology have made people realize their position in political activities (Mas'oed \& Andrews, 1991). Political modernization has a characteristic that in countries where the modernization process is stated to have been going well, it is usually followed by increased citizen participation. (Fadli et al., nd). It was reflected in the involvement in the 2018 West Java governor election, which has grown from the previous election.

The five interviewees interviewed by the researcher agreed that voting is a right, a right that cannot underestimate, a request that determines one's choice even if it is only one vote. Like the opinion of Neneng, that "Our vote determines the future of the nation, at least in West Java. We participated indirectly in determining the policies of the government for the next five years, we play an active role there by coming to the polling stations (voting)."Neneng, n.d.) Another resource person, such as Lustria Rahayu, a resident of R.W. 10, also stated that "One voice participates in determining what West Java will do next, do you want to change it."(Lustria Rahayu, nd) Then there is a similar opinion from Dede, that "Women have now begun to have a will to be equal to men, through elections that desire is channeled."(Dede, n.d.)

The opinion of one resident, namely Dewi, that most individuals thought that women's rights to be elected and to vote were something that they were born with, but the facts are different and full of struggle to achieve it. (Goddess, nd) For this reason, women's participation in voting is something important; women's voices are the same as men's voices. One person, one vote, regardless of gender, as Titi Anggraini argued that it is important to participate because, in the concept of democracy, political equality is one person, one vote, one value. No one was left behind.

Moreover, women were half of the total voting rights users. Hence the presence of women is part of the existence of democracy itself. However, more importantly, women vote as a form of articulation to determine policy directions so that not only physical representation is attended through voting rights but how the struggle for interests/aspirations is also facilitated through voting rights that reflect women's political agendas."(Titi Anggraini, nd)

Modernization is also followed by the more active involvement of women in the public sphere. Several interviewees who were interviewed in this study were not only involved in voting but also in existing public spaces, such as being active in Maleer Village as administrative assistants (things related to I.D. cards, birth certificates, and others) as 
being party sympathizers. Another female resource person had also been Chair of R.W. 01 for five (5) periods since 1998, Chair of the longest R.W. in Maleer Village, and Chair of PPK Batununggal (the only female PPK Chair in Bandung City) in the 2018 West Java Governor Election. Active as a member of the Maleer Village PKK and a party sympathizer, I witnessed during the 2018 West Java governor election. There was also a student from one of the existing universities. The same thing regarding the activeness of women in the public world was conveyed by Suharti, the Technical and Participation Division of the Bandung City General Election Commissions, that in every election implementation, each PPK (Subdistrict Election Committee), PPS (Voting Committee), and KPPS (Voting Organizing Group) has a women's representatives as organizers in Subdistrict Election Committee, Voting Committee, and Voting Organizing Group. Women did not just vote but also acted as organizers, even in Panwascam, whose job was to supervise all men and women. It becomes part of women's participation in general elections or the regional elections. (Suharti, nd)

In the General Election in the Maleer region, affirmative action appears (30\% women's representation). It made at least the organizers of Voting Organizing Group, Voting Committee, Subdistrict Election Committee, and the City General Election Commission and Provincial General Election Commission filled by women. However, quantitatively they were not equal to men, even though there was no single female candidate pair in the 2018 West Java governor election. Women feel represented that they feel comfortable coming to polling stations, witnessing political parties at polling stations, or participating in monitoring the course of the existing elections.

\section{Conflicts between groups of political leaders}

The 2018 West Java governor election held on June 27, 2018, was after the 2017 DKI Regional Head Election and ahead of the 2019 Presidential Election. The increasing identity politics that occurred since the 2017 DKI Regional Head Election impacted the 2018 West Java Governor Election to the 2019 Presidential Election, and it caused a polarization that quite divided in society.
Political elites who competed in the 2017 DKI Regional Head Elections, 2018 West Java Governor Elections, and 2019 Presidential Elections led to a polarization that gave group identity similarities. The emergence of conflict stimulated the community to participate. The incident in the 2018 West Java Governor candidate pair debate where pair number 3 , Sudrajat-Syaikhu, unfurled the \#2019ChangePresident shirt when the discussion was about to end, causing a riot during the discussion. The symbols of association with certain pairs of presidential candidates strengthened to gain votes due to the existing polarization.

Titi Anggraini Mashudi, as Executive Director of the Election and Democracy Association, explained that we must know the landscape of the West Java Pilkada, which cannot be separated from the atmosphere after the 2017 DKI Jakarta Pilkada. Strong polarization did characterize DKI Jakarta and the environment around DKI Jakarta, including West Java and Banten. Then, the West Java governor election was also in disunity ahead of the 2019 general election. Entering June 2018, according to Titi, many power maps had emerged for the nomination of figures in the 2019 election. Titi believed that it could not separate even female voters from the current political struggles after the DKI Jakarta election. He continued that there were groups that reflected the escalation in the DKI Jakarta Election and reflected that in the campaign approach of the candidate pairs in the 2019 election. Titi believed that the debate and hashtag \#2019 Change President also triggered male and female voters to come to polling stations. Titi assessed that women had the characteristics of being politically loyal and were easier to move to the polling stations. It was coupled with the escalation of polarization after the DKI Jakarta Election and ahead of the 2019 election, especially in the \#2019 Change President and \#2019 Permanent Jokowi or \#Jokowi2 Period dichotomy. (Titi Anggraini, nd)

Women also experienced polarization. Identity politics that has emerged recently dominated the pattern of community participation. The community seemed to have already chosen packages based on the current polarization. The researchers, in this case, 
interviewed residents of R.W. 02, Tjutju, based on Tjutju:

"Choose Mr. Jokowi. Yes, he has been promoted, we have met him and the construction is good in Bandung (Ridwan Kamil)."(Tjuju, nd)

How the choice of the governor candidate directs the selection of the presidential candidate. Identity Politics seeds to provide a package of group choices. Loyalty and totality were shown by the options that follow the box of choices offered. For example, the Sudrajat-Syaikhu pair openly supported presidential candidates other than Joko Widodo with their slogan \#2019ChangePresident.

The most prominent identity designation in the 2018 West Java governor election was on Sundanese culture and Islam. The governor candidates presented both elements in their approach to voter choice. The 2018 West Java governor election contestation became an arena for spreading hatred among human beings who had different political views or did not share the same faith. For example, Ridwan Kamil was repeatedly rumored that he was a Shia and was said to have defended Ahok's supporters because of lighting 1000 candles by Ahok's supporters in Bandung. (Slamet, nd)

Agnes Heller (Abdilah, 2002) assumed identity politics as politics whose main point was the difference as a sign of real politics. After the failure of the grand narrative, though, new threats would emerge. Various forms of intolerance, violent practices were increasingly widespread. Conflicts between elites to seize power using identity politics and could not be denied caused problems at the grassroots. The condition of the community heated up every time they discussed the election, especially the distance of the West Java Governor Election, which was close to the 2019 election.

\section{The Behavior of Women Voters in the 2018 West Java Governor Election}

West Java, as a province with a voter turnout of 32,325,315 people (Results of Determination of West Java, 2018), was the first largest number of voters in Indonesia. West Java is one of the important areas to be contested by political parties/contestants to maintain the national vote. Therefore, the election of the governor of West Java attracted the enthusiasm of political actors, political parties, and political observers in every implementation. The following is data on the 2018 West Java Governor Election in Maleer Village, Bandung City.

Table 3. Votes for the 2018 West Java Governor Election in Maleer Village, Bandung City (KPU,2018)

\begin{tabular}{llll}
\hline No. & Candidate Pair & Number of Votes & Percentage \\
\hline 1 & Ridwan Kamil - Ruzhanul Ulum Law & 4,700 & $54.73 \%$ \\
\hline 2 & Hasanuddin - Anton Charliyan & 782 & $9.11 \%$ \\
\hline 3 & Sudrajat- Ahmad Syaikhu & 2.053 & $23.91 \%$ \\
\hline 4 & Deddy Mizwar - Dedi Mulyadi & 1.052 & $12.25 \%$ \\
\hline
\end{tabular}

Source: KPU RI

Based on the data from the Bandung City General Election Commission, the results of the recapitulation of votes in Maleer Village are as follows: Mochamad Ridwan Kamil and UU Ruzhanul Ulum (sequence number 1) received 4,700 votes $(54.73 \%)$, Major General TNI (Ret.) Hasanuddin and Inspector General of Police (Ret.) Anton Charliyan (number 2) received 782 votes $(9.11 \%)$, Major General TNI (Ret.) Sudrajat and Ahmad Syaikhu (number 3) received 2,053 votes (23.91\%), and Deddy Mizwar and Dedi Mulyadi (number 4) obtained 1,052 votes $(12.25 \%)$. The 2018 West Java governor election contest in Maleer Village was won by pair number 1 , far ahead of its competitors.

Should take Women as voters into account. It is since women could be a decisive voice. It became interesting to look at the approach to voter behavior to find out why one person chose a particular contestant and why not another contestant? (Heryanto, 2019) To answer this, there are three approaches used;

First, a sociological approach emphasizes voters' sociological background, such as social class, religion, and ethnic/regional groups(Mujani et al., 2012). Second, a 
psychological approach is emphasized by three psychological aspects that influence voter behavior: emotional attachment to a political party, orientation to issues, and exposure to political figures(Upe, 2008). Third, a rational choice approach that emphasizes consumers are judging choices based on available policy options. They will use the market analogy (profit and loss) in selecting candidates and their vision, mission, or policies(Heywood, 2013). Based on the description above, the researcher found out the behavior of women voters based on the three approaches previously mentioned.

a) Women choose based on the figure.

In this study, the researcher did not find that voters in Maleer Village voted based on the sociological background of the candidates. The interviewees did not make their choices based on the similarity of religion, ethnicity, gender, and so on as a benchmark, even though identity politics strengthened in the contestation in the 2018 West Java Governor Election. In the voter approach based on psychological aspects, party identity (party I.D.), opinions related to the personality qualities of party figures or candidates fighting in elections are aspects in making choices according to a psychological approach(Mujani et al., 2012).

Female voters in Maleer Village voted because of the influence of political figures, in this case, the candidate for governor. Voters feel close (adore) with certain political figures. The victory of the Ridwan Kamil-UU Ruzhanul Ulum pair in Maleer Village could not be separated from the formation of Ridwan Kamil. He became the Mayor of Bandung before running for the 2018 West Java Governor Election. Ridwan Kamil, when he served as Mayor, was known to be active on social media. In the era of social media, political participation was growing. By society, social media was used as a new medium in expressing their political participation. Meanwhile, social media was a unique platform for politicians for communicating, conducting campaigns, and spreading political ideas to the public(Munzir et al., 2019).

Based on Myron Weiner, mass communication is a factor that affects the level of community participation. The development of modern communication and information technology has accelerated the spread of new ideas to the general public (Mas'oed \& Andrews, 1991). The result of communication technology causes the mass media to grow as a controlling force of power and as political, economic, and cultural power. Through the media, views, ideas, information and discourse are exchanged, and the progress of society is also reflected in it (Habibie, nd). Such an interview with a resident of R.W. 05, Elis Komalawati:

"Mother was active on social media since she did the makeup at the salon, so on social media, displayed her skills. Because she was also active on social media, she also often accesses political news either through

"Looking for news through online $h$ W.A., Facebook, Instagram and postings of activities in the Democratic Party as well."(Komalawati, nd)

Lustria Rahayu also stated the important role of technology/media in providing references for voters: media, first to find out the candidate's identity, besides the latest news/information from the governor candidate. For example, if I served in the past, I would find out about the results of that person's work." (Lustria Rahayu, nd)

A similar opinion was also conveyed by Dede, that he has received a preference for choosing a figure from social media, partly from members of the party branch. Based on Dede, it was also important to find out the people's performance we will choose in the future in terms of social and development (Dede, nd). The assumption that women's time was running out for taking care of their domestic and family was contradicted by the informant's opinion above, that women were also able to make the best use of technology. Women's speed of growth and optimal use of technology can be claimed as extraordinary (Ministry of Women's Empowerment and Child Protection, 2018). Women started looking for information about competing candidates, such as track records, indicating that women were actualizing themselves to advances in science and technology.

Yogaswara, in his book, wrote that talking about the leadership style, Ridwan Kamil believed that today's society needed a leader who has a sky-high vision but is still humble. Ridwan Kamil thought that the leader he was looking for was a leader who was proactive in making changes, not just sitting 
quietly behind a desk. Based on Emil, a leader must go to the field, chat with residents, and interact because changes must be picked up(Yogaswara, 2018). Ridwan Kamil has made an impression in the community, and Ridwan Kamil is considered close to the community and not distant. One of the research sources, Tjutju, explained the reasons for choosing Ridwan Kamil;

"Ridwan Kamil, a social person, authoritative, can be nurturing, small communities are easy to contact."(Grandma, nd).

Social media is a means of interaction of two or more people simultaneously without the need to think about distance, speeding up communication messages conveyed without the need for direct physical presence. Ridwan Kamil used social media to socialize his work programs as Mayor of Bandung, such as Rebo Nyunda. ${ }^{1}$, Revitalization of the Park Equipped with Wifi, Bandung Vision Wins, Earth Hour Campaign, Thursday England ${ }^{2}$ And the others (Wulansari, nd). However, some risks will be experienced by leader figures from free social media. Unwise users can create negative news addressed to potential leaders through various social media.

b) Women vote based on the candidate's program/work.

Based on Myron Weiner (Mas'oed \& Andrews, 1991), the expansion of government activities in new policy sectors usually resulted in government actions interfering with all aspects of people's daily lives. It would affect political participation. The role of the government, whether through programs or efforts, had an impact on people's lives and presented pros and cons. Government activities through programs that were in direct contact with the community caused a term called rational choice in the discussion of voter behavior. This behavior focuses on the belief that humans are creatures who have material interests for themselves. Simply, there is a profit-and-loss calculation before making that choice (Mujani et al., 2012).

\footnotetext{
${ }^{1}$ Every Wednesday program that familiarizes the people of Bandung City to use Sundanese.

${ }^{2}$ Every Thursday program that familiarizes the people of Bandung City to use English.
}

Before becoming Mayor of Bandung, Ridwan Kamil was better known by the residents of Bandung City as a lecturer at ITB (Bandung Institute of Technology) and professionals working in the field of Urbane architecture. ${ }^{3}$ When he became Mayor, Ridwan Kamil used his architectural touch in organizing the City of Bandung. Infrastructure development such as buildings and thematic parks has become a symbol of Bandung City. After being sworn in as Mayor, Ridwan Kamil immediately touched the parks of Bandung City. Kang Emil called the park a thematic park, and his goal was to open a Green Open Space (RTH). Based on Law No. 26 of 2007 concerning Spatial Planning, it is stated that the area of green open space must reach a minimum of $30 \%$ of the city area (Pitoyo, 2018).

Revitalization of green open space was quite difficult in the City of Bandung due to limited land. However, the area of green open space increased from $11.9 \%$ in 2013 to $12.21 \%$ during the leadership of Ridwan Kamil. A figure of 1 percent was equivalent to 164 hectares. (H.K. Bandung, nd). The impact of the program during Ridwan Kamil's leadership was felt by the community, one of which was Elis Komalawati:

"... it's already seen in the construction field, yes, it's already felt. Organizing the City which was previously chaotic, then changed to be neatly organized. The program organized the environment, plants, reforestation. The environmental program has already been included in the VillageVillage and in the City."(Komalawati, nd) opinion:

Lustria Rahayu also shared a similar

"Now there are parks everywhere, so residents can play in the park so the residents can gather there."

The presence of thematic parks in various corners of Bandung city has been the expectation of Bandung people since before 2013. The Bandung City Government has succeeded in adding green open spaces, which were a producer of fresh air and a gathering

\footnotetext{
${ }^{3}$ Urbane Indonesia is a developer consultant in infrastructure and interior design based in Bandung and spearheaded by Ridwan Kamil and his friends.
} 
place for families, communities, and as a recreational place of choice for residents. Both local and out of Bandung city. Thematic parks that were friendly for women and children were programs felt directly for women and families. Tjutju felt the same way:

"... It's comfortable on the streets, since the view is the creation of Mr. Ridwan Kamil, the construction is so great (parks and buildings)."(Tjuju, nd)

In addition to adding green space in the Bandung city, the Bandung city government was carrying out a public transportation revolution. The operation of many buses in Bandung city, such as Trans Metro Bandung (TMB), corridors and bus stop, free school buses, and adequate public transports (called Damri). Especially for the Damri bus, the condition was much better than a few years ago, where the exhaust was still billowing. Damri has received the assistance of a new bus unit from the West Java Provincial Government now so that it was convenient to use as public transportation. (Riswan, nd) It is also similar to the opinion of Lustria Rahayu;

"... The means of transportation have also started to be improved, started to be put in order again, held again. In the past, it wasn't very well taken care of, now there are stops, there weren't any before."(Lustria Rahayu, nd)

Ridwan Kamil's artistic touch did not stop at the thematic gardens and squares. The art of infrastructure development both buildings and roads in Bandung city looks so beautiful. Antapani Bridge or the Rainbow Bridge, with a touch of art and creativity, brings a new impression in making bridges far from the slum. (Nurmatari, nd)Women can enjoy public facilities in Bandung city more comfortably and friendly. After Ridwan Kamil made many community breakthroughs, Kang Emil further involved the community through the Regional Development and Empowerment Innovation Program (PIPPK). The program, which started in 2015 , has a decentralization concept that extends to the community.

The community organized, discussed, and made programs that were needed by their environment. PIPPK provided funds of 100 million to sub-districts to empower their regions by facilitating R.W. (VillageVillage), PKK, Karang Taruna, and LPM. 1 R.W. got 100 million to accelerate the development of both infrastructure and human resources from the ground up. The researcher interviewed a resident named Neneng regarding this matter; "PIPPK, funds that went directly to the community, one R.W. (village) 100 million is Ridwan Kamil's program, Ridwan Kamil's real program for the community."(Grandma, nd)

Based on the opinion of female informants, female voters in choosing their candidates already understood what would be gained from the voting mechanism. Programs or tangible results of a prospective leader became a benchmark in selecting candidates. Titi Anggraini, as the Director of Perludem, explained that we have to observe how the politics of ideas, programmatic interactions/program transactions between voters and candidates have not yet fully emerged."(Titi Anggraini, nd).

Gender inequality against women occurred in terms of political participation. There was an assumption that women's voices do not influence the decision-making process, especially public interest(Vries, 2006). Based on feminist groups, defining personal issues into general political issues is significant to discuss, such as housework, sexuality, reproduction, child care, etc.(Disch \& Hawkesworth, 2016). It needed to be fought for by women, and having comprehensive information about the candidate's work program was a good step in considering choosing. It can be seen in the female voters in Maleer Village who fell into female voters with rational choice behavior.

\section{CONCLUSION}

Based on the level of women's participation, several factors influenced the participation of women voters in Maleer Village, Bandung, West Java, namely; modernization factors, modern mass communication, and conflicts between groups of political leaders as factors that led to an increase in women's participation in the 2018 West Java governor election in Maleer Village. In the form of modernization, women became more involved in the public sphere/political activities. While in modern mass communication, the activeness on social media was used by mothers to access political news, either through WhatsApp, Facebook, Instagram, and others. The media has become a preference for female voters to vote, whether 
to find out which figures were running for office, etc.

Regarding voter behavior, in this study, women did not vote based on the sociological model but based on the psychological model and rational choice. In the psychological model, people felt close (adore) with certain political figures. Ridwan Kamil was described as a leader who combined conventional and modern communication in his government. In voter behavior seen from rational choices, female voters looked to Ridwan Kamil's programs and worked as their reference in voting. Schedules or tangible results from a prospective leader felt before became a benchmark in selecting candidates.

\section{BIBLIOGRAPHY}

Abdilah, U. (2002). Politik Identitas Etnis: Pergulatan Tanda Tanpa Identitas. Indonesia Tera.

Astuti, T. M. P. (n.d.). Citra Perempuan dalam Politik. Yin Yang, 3(1), 3-16.

Bandung, H. K. (n.d.). Pemkot Bandung Maksimalkan RTH demi Kota Berkelanjutan. Retrieved February 10, 2020, from http://humas.bandung.go.id/humas/layana n/pemkot-bandung-maksimalkan-rth-demikota-berkelanj

Bandung, K. K. (2013). Tingkat Partisipasi Pilgub Jawa Barat Kecamatan Batununggal.

Bibler, S., Mohan, V., \& Ryan, K. (2014). Kesetaraan Gender \& Penyelenggaraan Pemilu: Panduan Praktek Terbaik. IFES.

Budiarjo, M. (2013). Dasar-Dasar Ilmu Politik. PT Gramedia.

Dewi, K. H. (n.d.). Hak Pilih Perempuan Indonesia. Lipi.Go.Id. Retrieved February 4, 2020, from http://www.politik.lipi.go.id/kolom/23-hakpilih-perempuan-indo nesia

Disch, L., \& Hawkesworth, M. (2016). The Oxford Handbook of Feminist Theory. Oxford University Press.

Fadli, M., Bailusy, M. K., Nas, J., \& Zulfikar, A. (n.d.). Keterlibatan Elit Lokal Dalam Peningkatan Partisipasi Politik pada Pemilihan Bupati dan Wakil Bupati Kabupaten Toraja Utara Tahun 2015. Aristo, 6(2), 311-321.

Habibie, D. K. (n.d.). Dwi Fungsi Media Massa. Interaksi: Jurnal Ilmu Komunikasi, 7(2), 80.

Hasil Penetapan Jawa Barat. (2018). https://infopemilu.kpu.go.id/pilkada2018/h asil/penetapan/t1/jawa_barat

Heryanto, G. G. (2019). Literasi Politik: Dinamika Konsolidasi Demokrasi Indonesia Pascareformasi. IRCiSoD.

Heywood, A. (2013). Politics (4th ed.). PALGRAVE MACMILLAN.
Jdih.jakarta.go.id. (2016). Undang-Undang Republik Indonesia Nomor 10 Tahun 2016 tentang Perubahan Kedua Atas Undang-Undang Nomor 1 Tahun 2015 tentang Penetapan Peraturan Pemerintah Pengganti UndangUndang Nomor 1 Tahun 2014 tentang Pemilihan Gubernur, Bupati, dan Walikota Menjadi

https://jdih.jakarta.go.id/uploads/default/p rodukhukum/UU_Nomor_10_Tahun_2016.pd $\mathrm{f}$,

Kementerian Pemberdayaan Perempuan dan Perlindungan Anak, K. (2018). Profil Perempuan Indonesia 2018. https://www.kemenpppa.go.id/lib/uploads / list/d9495-buku-ppi-2018.pdf,

KPU. (2018). Perolehan Suara Pasangan Calon Gubernur Jawa Barat 2018 Kelurahan Maleer.

https://infopemilu.kpu.go.id/pilkada2018/h asil/rekap/t1/jawa_barat/kota_bandung/ba tununggal/maleer,

KPU. (2019). Hasil Rekap Jawa Barat Kota Bandung. https://infopemilu.kpu.go.id/pilkada2018/h asil/rekap/t1/jawa_barat/kota_bandung/ba tununggal/maleer,

Mas'oed, M., \& Andrews, M. C. (1991). Perbandingan Sistem Politik. Gajah Mada University Press.

Mujani, S., Lidlle, R. W., \& Ambardi, K. (2012). Kuasa Rakyat: Analisis tentang Perilaku Memilih dalam Pemilihan Legislatif dan Presiden Indonesia Pasca-Orde Baru. Mizan.

Munzir, A. A., Asmawi, \& Zetra, A. (2019). Beragam Peran Media Sosial dalam Dunia Politik di Indonesia. JPPUMA, 7(2), 178-185.

Nurmatari, A. (n.d.). Besok Jembatan 'Pelangi' Antapani Diresmikan Wapres Jusuf Kalla. Retrieved February 10, 2020, from https://news.detik.com/berita-jawabarat/d-3402979/besok-jembatan-pelangiantapani-diresmikan-wapres-jusuf-kalla

Pitoyo. (2018). Komunikasi Simbolik Ridwan Kamil. Grasindo.

Riswan, 0. (n.d.). Ridwan Kamil Tak Sabar Operasikan Bus Listrik di Bandung. Retrieved February 10, 2020, from https://otomotif.okezone.com/read/2016/0 8/19/15/1467809/ridwan-kamil-tak-sabaroperasikan-bus-listrik-di-bandung,

Sahid, K. (2011). Memahami Sosiologi Politik. Penerbit Ghalia Indonesia.

Slamet, A. (n.d.). Identitas Politik dalam Komunikasi Politik Calon Gubernur Jawa Barat Tahun 2018. Jurnal Linimasa, 2(1), 100-110.

Soetjipto, A. (2005). Politik Perempuan Bukan Gerhana. Penerbit Buku Kompas.

Solehudin, M. (2004). Tren Partisipasi Pilgub Jabar Sejak 2004 Terus Menurun. 
JPPUMA: Journal of Governance and Political Social UMA (UMA Journal of Governance and Political Social), 9 (2) (2021): 139-149

https://news.detik.com/berita-jawabarat/d-3649419/tren-partisipasi-pilgubjabar-sejak-2004-terus -menurun

Upe, A. (2008). Sosiologi Politik Kontemporer: Kajian Tentang Rasionalitas Perilaku Politik Pemilih di Era Pemilihan Kepala Daerah Secara Langsung. Prestasi Pustaka.

Vries, D. W. de. (2006). Gender Bukan Tabu: Catatan Perjalanan Fasilitasi Kelompok
Perempuan di Jambi. Center for International Forestry Research.

Wulansari, I. (n.d.). Artikulasi Komunikasi Politik Ridwan Kamil Dalam Media Sosial Twitter. Ultimacomm: Jurnal Ilmu Komunikasi, 6(2), 26-28.

Yogaswara, A. (2018). Kisah, Perjuangan, \& Inspirasi Ridwan Kamil. Checklist. 